DOI: https://doi.org/10.32838/2523-4803/71-4-15

УДК 332.341:332.3

Томашук I.B.

доктор філософії з економіки, асистент кафедри

економіки та підприємницької діяльності,

Вінницький національний аграрний університет

\title{
Tomashuk Inna
}

Vinnytsia National Agrarian University

\section{РОЗВИТОК СІЛЬСЬКИХ ТЕРИТОРІЙ В УМОВАХ ДЕЦЕНТРАЛІЗАЦІЇ ВЛАДИ В УКРАЇНІ}

\begin{abstract}
У статті розглянуто заходи реорганізації економічного механізму територіального управління 6 контексті децентралізаиії влади. Вказується, щчо реформа децентралізаиії безпосередньо пов'язана з розвитком та оптимальним використанням ресурсного потенціалу сільських територій. Наголошується, щуо однією з фундаментальних умов незалежності органів місиевого самоврядування $\epsilon$ фінансова децентралізаџія, яка відображає фінансові повноваження регіональних органів влади. Зазначається, щзо процес добровільного об'єднання територіальних громад створив передумови для трансформації територіальної структури та субрегіонального рівня. Підкреслюється, щуо в українських реаліях існує значний невикористаний потенціал інклюзивності у формі самоорганізаиіийої діяльності сільських територіальних громад та продуктивної діяльності сільського бізнесу y вирішенні місцевих сочіально-економічних проблем. Зроблено висновки, що територіальні громади можуть регулювати процес нагромадження коштів, надання відповідних послуг, базуючись на коротко- і довгостроковому плануванні. Також можна стверджувати, щзо децентралізацію слід розглядати як фактор, який прямо впливає на диверсифікацію розвитку сільських територій.

Ключові слова: дечентралізачія, сільські території, об'єднані територіальні громади, інклюзивний розвиток, потенціал, Державний фонд регіонального розвитку.
\end{abstract}

Постановка проблеми. Треба визнати, що нинішні труднощі українського села є проявом системних територіально локалізованих соціальних проблем, успішне вирішення яких залежить від державного механізму їх адміністративної та фінансової підтримки та місцевої ініціативи щодо створення нового середовища проживання мешканців сільської місцевості. У процесі становлення ринкової економіки сільська місцевість зазнала деструктивних змін, спричинених невідповідністю соціально-економічних трансформацій розвитку села інтересам сільських громад [10]. Надмірна централізація влади, яка спрямовувала органи місцевого самоврядування та самоорганізацію населення на виконання вимог компетентних структур, викликала необхідність докорінного перегляду соціально-економічної політики розвитку села.

Процеси розпаювання земель та майна сільськогосподарських підприємств в Україні, які здійснювалися без приведення у відповідність до нових умов управління та функціонування соціальної сфери села, структури органів та принципів державного управління соціально-економічним розвиток аграрного сектору, призвело до негативних наслідків. Виникла потреба у такій соціально-економічній політиці розвитку села, стратегічною метою якої було суттєве підвищення рівня життя населення на основі якісно покращеного вико- ристання ресурсного потенціалу, принципово нових підходів до формування продуктивних сил, докорінного вдосконалення екологічного стану регіонів. Обраний Україною вектор євроінтеграції вимагає формування принципів структурної політики розвитку села [15]. Крім того, важливого значення набуло обгрунтування заходів реорганізації господарського механізму територіального управління в контексті децентралізації влади, надання більшої самостійності регіонам і відповідальності за економічний і соціальний розвиток сільських територій на засадах приватно-державного партнерства, економічних методів управління, важелів та інструментів активізації господарської діяльності для підвищення рівня сільського розвитку.

Розгортання децентралізації нинішньої системи державного управління в Україні призводить до появи нових процесів та явищ у суспільному розвитку сільських поселень через посилення субрегіонального рівня управління, докорінні зміни принципів організації сільських громад та знаходження нових форм реалізації головних функцій місцевого самоврядування на локальному рівні, орієнтованих на самоорганізацію і саморозвиток громад [2; 7]. У складних суспільнополітичних та соціально-економічних умовах країна швидко впроваджує реформу децентралізації зі значними економічними та соціальними ризиками, мож- 
ливими негативними наслідками для сільських громад, які наразі недостатньо поінформовані про характер перетворень i, по суті, не готові до таких радикальних змін з різних об'єктивних та суб' єктивних причин $[1 ; 5]$. Внаслідок цього часто виникають соціальні конфлікти, які лише ускладнюють умови ведення сільського бізнесу або погіршують загалом умови життя сільських мешканців.

Виходячи 3 цього, у статті розглянуто можливі сценарії розвитку сільських поселень в умовах децентралізації управління, їх вплив на організацію життєдіяльності сільських громад, сформований потенціал до саморозвитку. Визначено інституційні пастки на шляху розвитку сільських поселень в умовах об'єднання сільських територіальних громад та здійснення процесів децентралізації управління.

Аналіз останніх досліджень та публікацій. Стратегічні принципи розвитку сільських територій в контексті децентралізації влади стали предметом поглибленого дослідження вітчизняних та зарубіжних вчених, зокрема I.В. Гончарук, О.В. Довгаль, В.С. Єгорова, Т.А. Заяць, Г.М. Калетніка, Т.В. Ємчик, Ю.О. Лупенка, В.В. Луцяка, К.В. Мазур, Р.П. Мудрак, В.В. Лагодієнко, Н.В. Лагодієнко, А.В. Мовчанюк, В. Россохи, М. Плотнікова, М.П. Талавиря, А.О. Горай, I.О. Цимбалюк, О.Г. Шпикуляка, Г.Ф. Мазур та інших.

Наукові праці цих авторів присвячені вирішенню важливих проблем. Однак їм бракує системно-інтеграційного підходу до територіального управління розвитком сільської місцевості в контексті децентралізації влади та формування й перспектив розвитку об'єднаних територіальних громад, що актуалізує науковий пошук у цій галузі досліджень.

Формулювання цілей статті (постановка завдання). Метою статті $є$ розгляд стану, проблем, законодавчого забезпечення, тенденцій та обгрунтування шляхів розвитку сільських територій в умовах децентралізації управління та адміністративнотериторіальної реформи.

Виклад основного матеріалу дослідження. Після схвалення Кабінетом Міністрів України Концепції реформування місцевого самоврядування та територіальної організації влади в Україні, що стало однією з вимог Міжнародного валютного фонду, розпочався процес децентралізації влади. У межах проведення реформи місцевого самоврядування було прийнято Закон України «Про співробітництво територіальних громад», який визначив організаційноправові засади співробітництва територіальних громад, принципи, форми, механізми такого співробітництва, його стимулювання, фінансування та контролю [15]. Виникла потреба у такій соціально-економічній політиці сільського розвитку, стратегічною метою якої було суттєве підвищення рівня життя населення на основі якісно покращеного використання ресурсного потенціалу, принципово нових підходів до формування продуктивних сил, радикального поліпшення екологічного стану регіонів [4; 9].
Важливого значення набуло обгрунтування заходів реорганізації господарського механізму територіального управління в контексті децентралізації влади, надання більшої самостійності регіонам і відповідальності за економічний і соціальний розвиток сільських територій на засадах приватно-державного партнерства, економічних методів управління, важелів та інструментів активізації господарської діяльності для підвищення рівня сільського розвитку $[3 ; 11]$.

Реформа децентралізації безпосередньо пов'язана 3 розвитком та оптимальним використанням ресурсного потенціалу сільських територій. Зокрема, у преамбулі до Концепції реформування місцевого самоврядування та територіальної організації влади в Україні зазначено, що наразі проблеми, які безпосередньо стосуються розвитку сільських територій, мають бути вирішені ефективно та швидко (табл. 1).

Сьогодні реформа децентралізації в Україні виходить на новий етап, який окреслено в реалізації шести головних завдань (рис. 1).

Закріплюється матеріально-фінансова основа місцевого самоврядування. Зокрема, визначено, що такою основою $є$ земля, рухоме та нерухоме майно, природні ресурси, інші об'єкти, які перебувають у комунальній власності територіальної громади; місцеві податки та збори, частина національних податків та інші надходження місцевих бюджетів [10].

Пропонується визначити, що держава забезпечує пропорційність фінансових ресурсів та обсяг повноважень органів місцевого самоврядування, визначених Конституцією та законами України. Однак децентралізація не означає послаблення центральної влади у таких питаннях, як оборона, зовнішня політика, національна безпека, верховенство права, повага прав i свобод людини [4; 16]. Децентралізація - це процес перерозподілу чи розповсюдження функцій, повноважень, людей чи речей від центральної влади. В умовах децентралізації можливості для розвитку села розширюються.

Останні події в Україні показують, що люди в місцевих громадах готові об'єднуватись та брати на себе ініціативи розвитку. Наміри євроінтеграції України вимагають великої кількості різноманітних реформ, включаючи фінансову децентралізацію, тобто фінансове забезпечення [7]. У табл. 2 наведено основні проблеми сільських територій, які має вирішити реформа децентралізації в Україні.

Однією 3 фундаментальних умов незалежності органів місцевого самоврядування є фінансова децентралізація, яка відображає фінансові повноваження регіональних органів влади. Обов'язковою умовою ефективного інституту самоврядування $є$ формування більшості доходів місцевих бюджетів разом із місцевими податками та зборами, які самостійно встановлюються органами місцевого самоврядування. Об'єднана громада отримує додаткові фінансові та майнові ресурси [5; 14]. Крім того, об'єднана територіальна громада має право самостійно розпоряджатися земель- 
Основні проблеми розвитку сільських територій в Україні

\begin{tabular}{|c|c|}
\hline № & Основні характеристики \\
\hline 1 & $\begin{array}{l}\text { Погіршення якості та доступності державних послуг через ресурсну нездатність переважної більшості органів місце- } \\
\text { вого самоврядування здійснювати власні та делеговані повноваження; }\end{array}$ \\
\hline 2 & $\begin{array}{l}\text { зношування теплових мереж, каналізації, мереж водопостачання та житлового фонду та ризик техногенних катастроф в } \\
\text { умовах обмежених фінансових ресурсів місцевого самоврядування; }\end{array}$ \\
\hline 3 & $\begin{array}{l}\text { важка демографічна ситуація у більшості територіальних громад (старіння населення, депопуляція сільських територій } \\
\text { та монофункціональних міст); }\end{array}$ \\
\hline 4 & невідповідність місцевої політики соціально-економічного розвитку реальним інтересам територіальних громад; \\
\hline 5 & $\begin{array}{l}\text { нерозвинені форми прямої демократії, нездатність членів громади діяти солідарно для захисту своїх прав та інтересів у } \\
\text { співпраці з органами місцевого самоврядування та місцевими органами виконавчої влади та досягнення спільних цілей } \\
\text { розвитку громад; }\end{array}$ \\
\hline 6 & $\begin{array}{l}\text { зниження рівня професіоналізму посадових осіб місцевого самоврядування, зокрема через низьку конкурентоспромож- } \\
\text { ність органів місцевого самоврядування на ринку праці, зниження престижу посад, що призводить до низької ефектив- } \\
\text { ності прийняття управлінських рішень; }\end{array}$ \\
\hline 7 & $\begin{array}{l}\text { корпоратизація органів місцевого самоврядування, закритість і непрозорість їх діяльності, високий рівень корупції, що } \\
\text { призводить до зниження ефективності використання ресурсів, погіршення інвестиційної привабливості територій, зрос- } \\
\text { тання соціальної напруги; }\end{array}$ \\
\hline 8 & надмірна централізація повноважень органів виконавчої влади та фінансових й матеріальних ресурсів; \\
\hline 9 & $\begin{array}{l}\text { усунення місцевого самоврядування від вирішення питань у сфері земельних відносин, посилення соціальної напруж } \\
\text { ності серед сільського населення через відсутність всюдисущості місцевого самоврядування. }\end{array}$ \\
\hline
\end{tabular}

Джерело: [3]

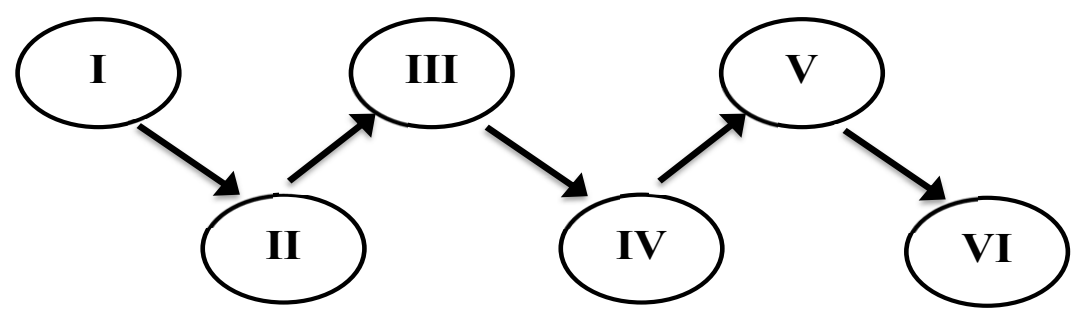

Рис. 1. Головні завдання реформи децентралізації в Україні

I - Формування нової територіальної основи для діяльності органів влади на рівні громад і районів.

II - Передача повноважень органів виконавчої влади органам місцевого самоврядування та їх розмежування за принципом субсидіарності.

III - Створення належної ресурсної бази для здійснення повноважень органів місцевого самоврядування.

IV - Формування ефективної системи служби в органах місцевого самоврядування.

$\mathrm{V}$ - Упорядкування системи державного контролю та нагляду за законністю діяльності органів місцевого самоврядування.

VI - Розвиток форм прямого народовладдя: виборів, референдумів.

Джерело: [6]

ними ресурсами своєї громади як у межах населених пунктів, так і за їх межами в межах адміністративних кордонів території об'єднаної громади.

Об’єднані територіальні громади мають прямі міжбюджетні зв'язки з державним бюджетом. До реформи вони мали лише обласні та районні бюджети, бюджети міст обласного значення. Для виконання делегованих державою повноважень їм надаються відповідні трансферти: гранти, освітні та медичні субвенції, субвенції на розвиток інфраструктури громади тощо. Зміни законодавства також надавали місцевим органам влади право затверджувати місцеві бюджети незалежно від дати прийняття закону про Державний бюджет. [4]. На рис. 2 наведено інформацію щодо виконання власних доходів місцевих бюджетів в Україні за січень-листопад 2019 р. порівняно з січнем-листопадом 2018 р.
Державна політика України у сфері місцевого самоврядування грунтується насамперед на інтересах мешканців територіальних громад і передбачає докорінні зміни та системні реформи, децентралізацію влади, тобто передачу від органів виконавчої влади органам місцевого самоврядування значної частини повноважень, ресурсів та відповідальності. Ця політика базується на положеннях Європейської хартії місцевого самоврядування та найкращих світових стандартах зв’язків з громадськістю у цій сфері [4].

Добровільне об'єднання територіальних громад протягом 2015-2020 рр. дало значний позитивний результат і зміни на краще. Тому сприяння максимальному подальшому процесу є одним з основних завдань. По всій території України мають бути створені спроможні та дієздатні органи місцевого самоврядування 
Проблеми сільських територій, які має вирішити реформа децентралізації в Україні

\begin{tabular}{|c|c|}
\hline \multicolumn{2}{|r|}{ Характеристика } \\
\hline \multicolumn{2}{|r|}{ Сформована оптимальна для України система адміністративно-територіального устрою } \\
\hline ЦІЛЬ 1 & $\begin{array}{l}\text { 1. Завершити розробку і затвердження Перспективних планів формування територій громад усіх областей України. } \\
\text { 2. Удосконалити механізм визнання об’єднаних територіальних громад спроможними за рішенням Кабінету } \\
\text { Міністрів України задля недопущення утворення ОТГ, неспроможних повноцінно виконувати визначені законом } \\
\text { повноваження. } \\
\text { 3. Визначити засади формування адміністративно-територіального устрою, умови та порядок утворення адміні- } \\
\text { стративно-територіальних одиниць, їх реорганізації через ухвалення окремого Закону «Про засади адміністра- } \\
\text { тивно-територіального устрою України». } \\
\text { 4. Завершити формування адміністративно-територіального устрою шляхом ухвалення законів про затвердження } \\
\text { адміністративно-територіального устрою кожної області на основі перспективного плану та утворення громад. }\end{array}$ \\
\hline \multicolumn{2}{|r|}{ Спроможне місцеве самоврядування, яке здатне здійснювати власні та делеговані повноваження } \\
\hline ЦІЛЬ 2 & $\begin{array}{l}\text { 1. Розширити базу оподаткування та можливості регулювання ставок місцевих податків і зборів, зокрема податку, } \\
\text { пов’язаного з нерухомістю. Перейти до аналогічної формули податку на нерухомість для фізичних осіб, як для } \\
\text { юридичних осіб; не визначати розмір площі, що не оподатковується; законодавчо обмежити діапазон для встанов- } \\
\text { лення податку, щоб не допустити його надмірності. } \\
\text { 2. Унормувати дохідну частину місцевих бюджетів відповідно до покладених на них видаткових повноважень. } \\
\text { 3. Вирішити питання поширення юрисдикції органів місцевого самоврядування об'єднаних територіальних гро- } \\
\text { мад на всю територію ОтГ. } \\
\text { 4. Надати право об'єднаним територіальним громадам затверджувати планування території ОТГ та управляти } \\
\text { земельними ресурсами в межах їхньої юрисдикції відповідно до затвердженої планувальної документації. } \\
\text { 5. Надати право органам місцевого самоврядування здійснювати контроль за використанням земельних ресурсів } \\
\text { відповідно до затвердженої містобудівної документації. } \\
\text { 6. Підвищити прозорість та ефективність використання бюджетних коштів через запровадження програмно-цільо- } \\
\text { вого методу складання та використання місцевих бюджетів. Запровадити процедури прозорого складання місце- } \\
\text { вих бюджетів за участі громадськості та звітування про виконання бюджету, електронні процедури для допорого- } \\
\text { вих закупівель тощо. } \\
\text { 7. Удосконалити механізм визначення обсягів субвенції на формування інфраструктури об'єднаних територіаль- } \\
\text { них громад та гарантування державою розміру фінансової допомоги. }\end{array}$ \\
\hline \multicolumn{2}{|r|}{ Громади беруть участь у вирішенні питань місцевого значення } \\
\hline ЦІЛЬ 3 & $\begin{array}{l}\text { 1. Запровадити ефективні механізми участі громадян у виробленні органами місцевого самоврядування рішень: } \\
\text { місцеві ініціативи, електронні петиції, громадські слухання, загальні збори громадян, громадські експертизи, кон- } \\
\text { сультативно-дорадчі органи, публічні консультації, громадські бюджети участі. } \\
\text { 2. Забезпечити право територіальних громад на місцевий референдум та визначити коло питань, які можуть роз- } \\
\text { глядатися на місцевому референдумі. } \\
\text { 3. Удосконалити процедуру створення органів самоорганізації населення, визначити чіткий порядок надання їм } \\
\text { частини повноважень органів місцевого самоврядування, окрім тих, що мають владний характер, а також надання } \\
\text { коштів для здійснення зазначених повноважень. }\end{array}$ \\
\hline \multicolumn{2}{|r|}{ Фінансування регіональної політики забезпечує розвиток та підвищує конкурентоспроможність громад і регіонів } \\
\hline ЦІЛЬ 4 & $\begin{array}{l}\text { 1. Збільшити розмір Державного фонду регіонального розвитку (ДФРР) до 1,5\% Державного бюджету, передба- } \\
\text { чивши при цьому спрямування } 1 / 3 \text { фонду на реалізацію загальнодержавних пріоритетів у регіонах. } \\
\text { 2. Удосконалити механізм розподілу коштів ДФРР, частину з яких спрямувати на фінансування реалізації Держав- } \\
\text { ної стратегії регіонального розвитку в регіонах на період до } 2020 \text { року. } \\
\text { 3. Запровадити прозорий процес відбору проєктів органів місцевого самоврядування на фінансування з ДФРР. } \\
\text { 4. Забезпечити моніторинг використання коштів ДФРР, контроль за відповідністю їх призначення встановленим } \\
\text { індикаторам ефективності, систему звітності. } \\
\text { 5. Забезпечити середньострокове бюджетування проєктів регіонального розвитку. } \\
\text { 6. Удосконалити процедуру підготовки проєктів у межах ДФРР шляхом визначення планованих обсягів коштів для } \\
\text { регіонів на наступний рік у січні поточного року. }\end{array}$ \\
\hline \multicolumn{2}{|r|}{ Держава контролюс законність діяльності органів місцевого самоврядування } \\
\hline ЦЛЬ 5 & $\begin{array}{l}\text { 1. Упорядкувати систему державного нагляду і контролю за діяльністю органів місцевого самоврядування через } \\
\text { ухвалення окремого закону. }\end{array}$ \\
\hline
\end{tabular}

Джерело: [13]

базового рівня - територіальні громади. Процес добровільного об'єднання територіальних громад створив передумови для трансформації територіального устрою і субрегіонального рівня. Наслідком $є$ те, що на районному рівні одночасно функціонують райдержадміністрація, райрада, виконавчі органи об'єднаних територіальних громад із визначеними законом повноваженнями, переважно дубльованими [4; 9]. На рис. 3 наведено динаміку утворених центрів надання адміністративних послуг в Україні у 2015-2019 рр., на рис. 4 наведено розподіл центрів надання адміністративних послуг в Україні у розрізі органів, що їх створили.

Саме тому для нагляду за додержанням Конституції та законів України органами місцевого самоврядування пропонується запровадити інститут префектів. Проєктом передбачено, що префекта призначає на посаду 


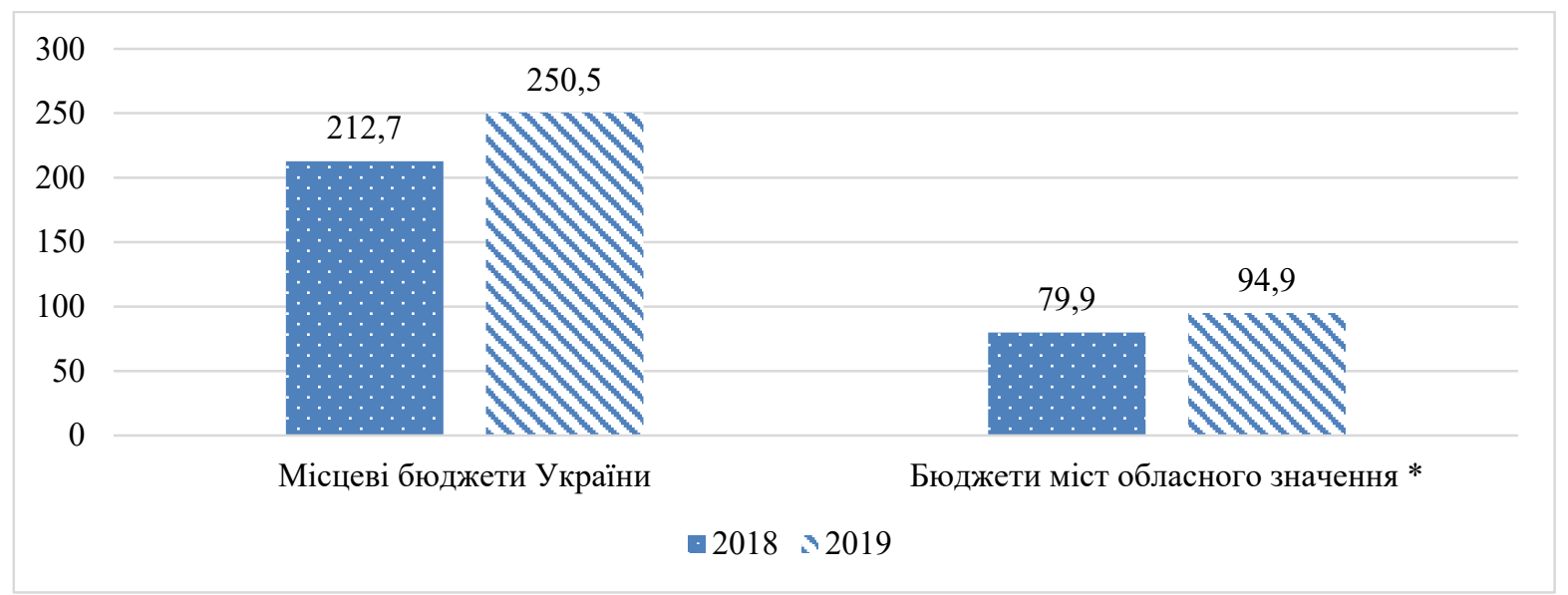

Рис. 2. Виконання власних доходів місцевих бюджетів в Україні за січень-листопад 2019 р. порівняно з січнем-листопадом 2018 р. млрд. грн. (\%)

*Без врахування 24 міст обласного значення, до яких приєдналися територіальні громади

Джерело: [2]

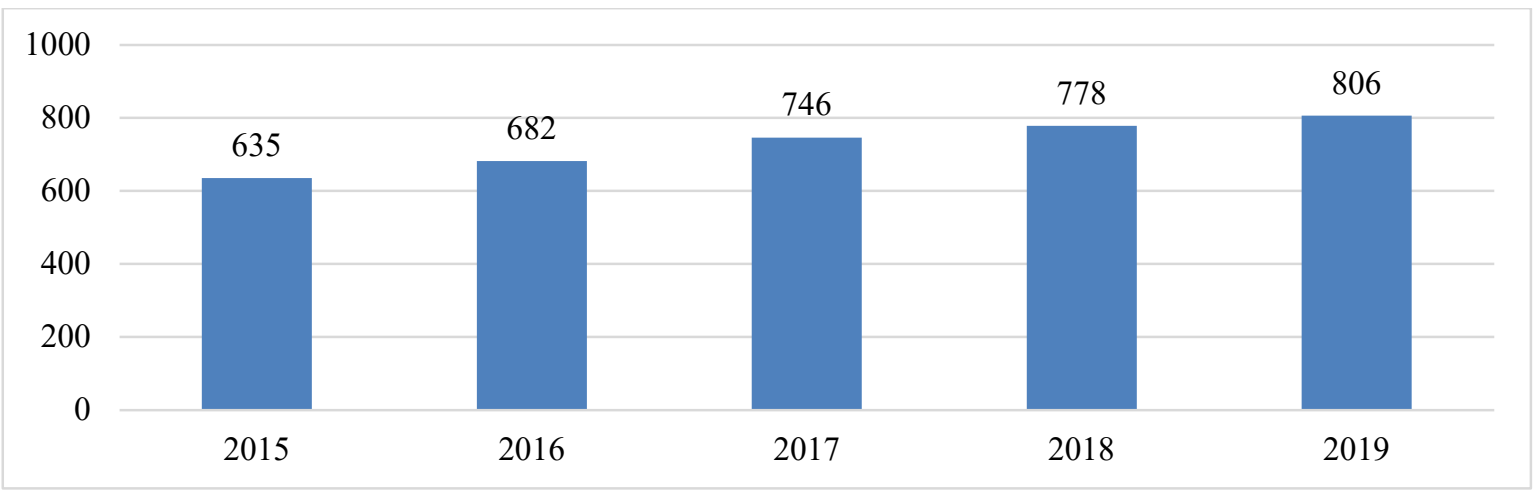

Рис. 3. Динаміка утворених центрів надання адміністративних послуг в Україні у 2015-2019 рр., одиниць

Джерело: [2]

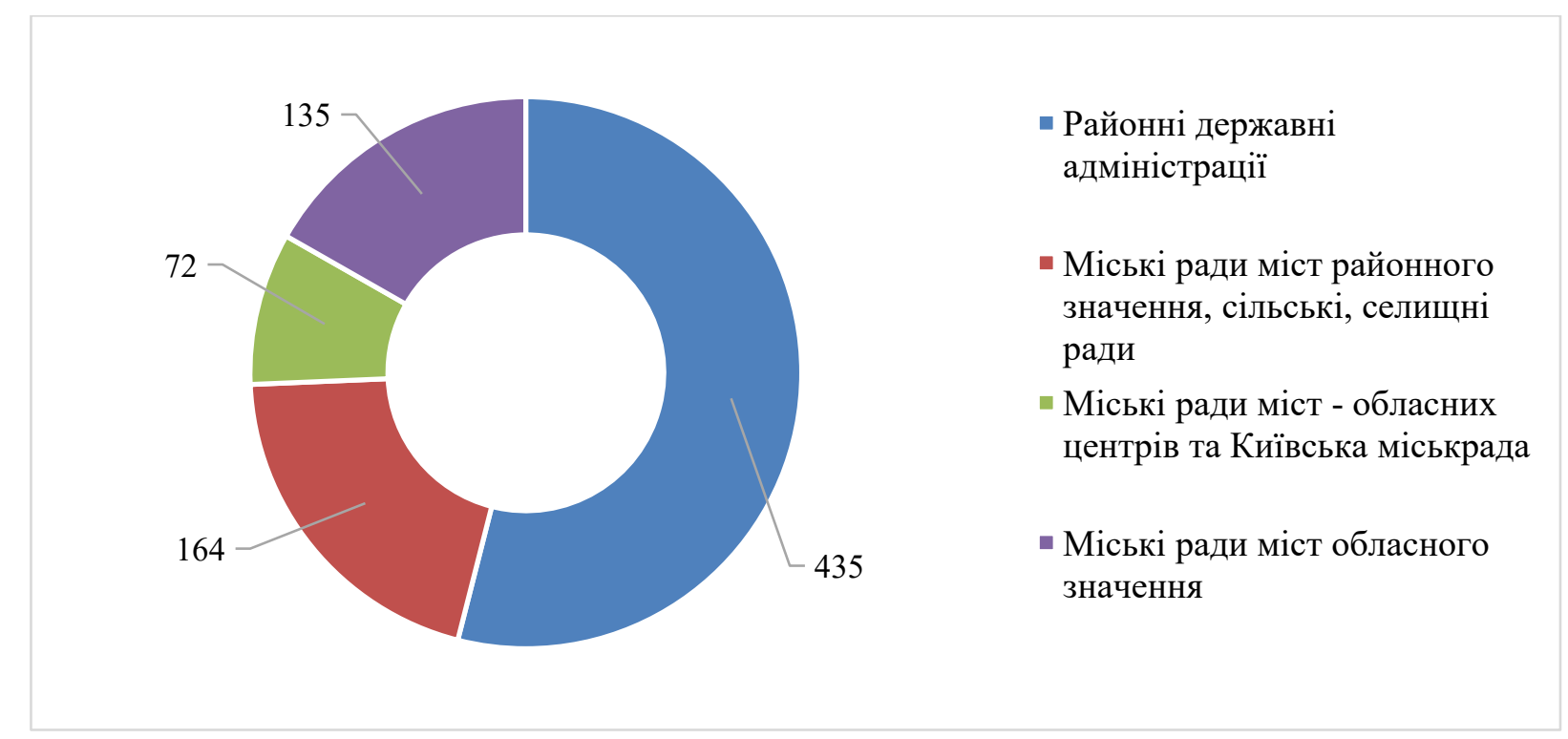

Рис. 4. Розподіл центрів надання адміністративних послуг в Україні у розрізі органів, що їх створили Джерело: [2] 
та звільняс з посади за поданням Кабінету Міністрів України Президент України. Префект зупиняє дію актів місцевого самоврядування 3 мотивів їх невідповідності Конституції чи законам України з одночасним зверненням до суду [6].

Станом на 10 січня 2020 року, в Україні створено 1029 об'єднаних територіальних громад з населенням 11,7 мільйона людей. Перспективними планами формування територій громад покрито 90,3\% території країни [2]. Крім того, значно активізувався 2019 року процес приєднання громад до ОТГ та міст обласного значення. Процедуру приєднання сусідніх громад пройшли вже понад 100 ОТГ. Загалом до них доєдналися майже 250 сусідніх сільських та селищних рад. За спрощеною процедурою понад 100 громад приєдналися до 44 міст обласного значення.

За минулий рік п'ятірка регіонів - лідерів реформи змінилася не суттєво. На початку 2019 року рейтинг областей $з$ формування спроможних громад очолювали Хмельницька, Житомирська, Чернігівська, Запорізька та Волинська області. На початку 2020 - Житомирська, Дніпропетровська, Чернігівська, Хмельницька та Запорізька області [2]. На рис. 5 та у табл. 3 наведена інформація щодо кількості створених ОТГ в Україні за 2015-2020.

Нагальна необхідність консолідації районів та громад, а також перерозподіл повноважень через роздробленість та невеликий розмір більшості територіальних громад, що призводить до їх фінансової неспроможності, нестачі резервів та ресурсів для власного економічного розвитку [3]. Сучасні зміни децентралізації в країні та іï регіонах здійснюються шляхом посилення самоврядування територіальних громад, які повинні чітко розуміти власні потреби та необхідність досягнення збалансованого розвитку поселень, бути достатньо мотивованими як постійні мешканці та зацікавлені в економічному зростанні та суспільному процвітанні.

Питання земельної реформи, яка фактично розпочалася разом з набуттям державної незалежності України, заслуговує на особливу увагу в реформі децентралізації. Головною метою земельної реформи було замінити неефективну, технологічно відсталу систему колгоспів, яка зосереджувалась на широкому використанні сільськогосподарських угідь на систему за європейським типом землекористування, що базується на потужних фермах, які грунтуються на функціонуванні приватної землі право власності $[1 ; 10]$.

Розглянемо досвід реалізованих проєктів сталого розвитку сільських територій в розвинутих європейських країнах, що дозволяє в них виділити основні акценти, які надалі можливо буде реалізовувати в Україні (табл. 4).

Вже сьогодні процес об'єднання місцевих громад сприяв передачі значної частки обов'язків з районів громадам. Відповідно до чинної Конституції України, безпосередньо обрані вищі регіональні ради нинішніх округів відповідають за представлення спільних інтересів населених пунктів у межах кожного такого округу.

Однак об'єднання часто призводить до створення відносно великих і могутніх ОТГ, які більше не потребують адміністративної підтримки рад чи керівників (тобто голів верхніх субрегіональних державних адміністрацій) на рівні району. Таким чином, більшість районів вже передали ОТГ широкі обов'язки та

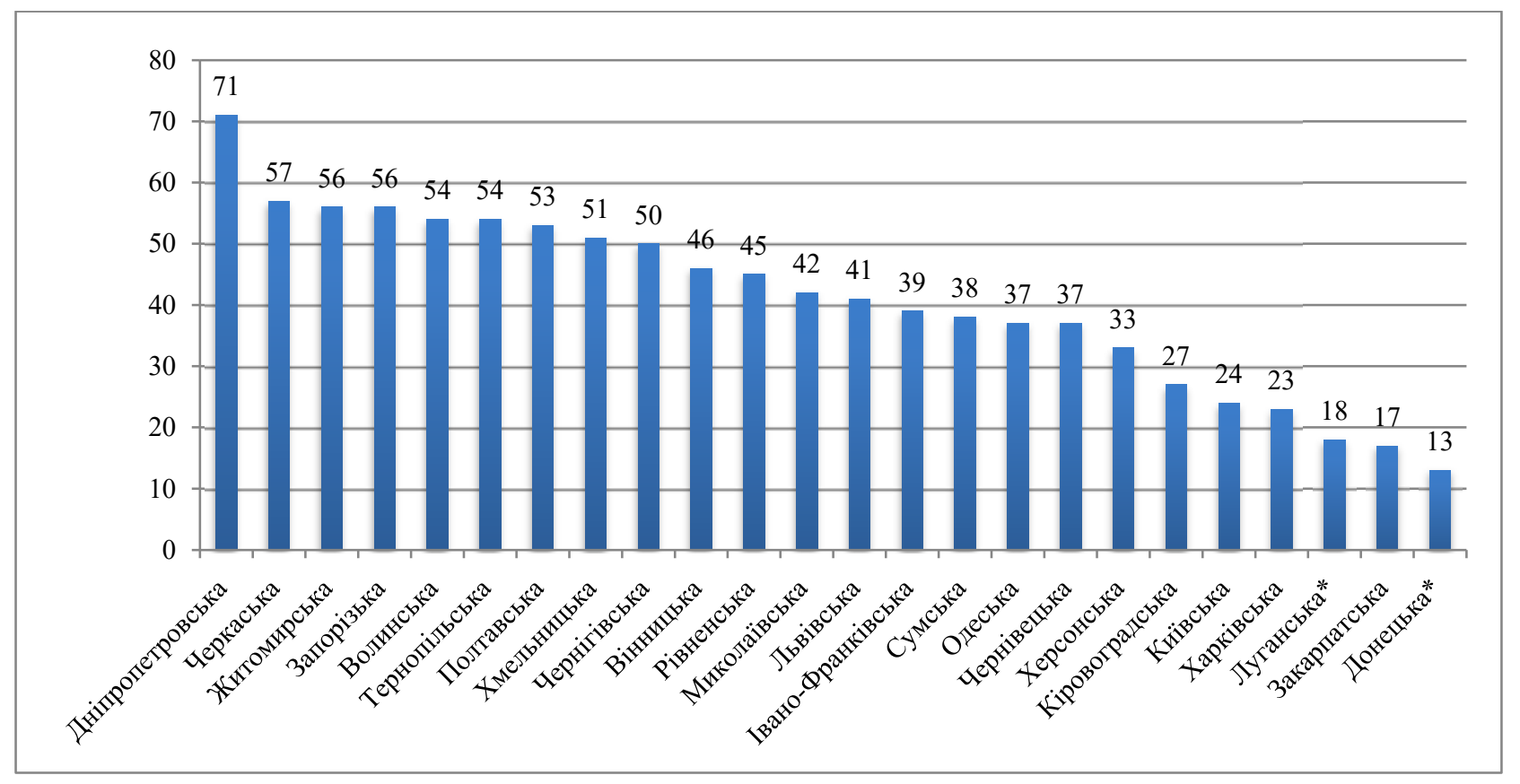

Рис. 5. Кількість створених ОТГ в Україні за 2015-2020, одиниць'

* Без урахування тимчасово окупованої території [2]

Джерело: [2] 
Таблиця 3

Кількість створених ОТГ в Україні за 2015-2020 рр., одиниць

\begin{tabular}{|c|c|c|c|c|}
\hline № & Назва області & $\begin{array}{c}\text { Кількість створених ОТГ } \\
\text { за 2015-2020 }\end{array}$ & $\begin{array}{c}\text { Перспективні плани спроможних } \\
\text { громад, затверджені Урядом }\end{array}$ & Відхилення, +/- \\
\hline 1 & Вінницька & 46 & 63 & 17 \\
\hline 2 & Волинська & 54 & 53 & 9 \\
\hline 3 & Дніпропетровська & 71 & 85 & 14 \\
\hline 4 & Донецька & 13 & 66 & 53 \\
\hline 5 & Житомирська & 56 & 65 & 9 \\
\hline 6 & Закарпатська & 17 & 64 & 47 \\
\hline 7 & Запорізька & 56 & 67 & 11 \\
\hline 8 & Івано-Франківська & 39 & 61 & 22 \\
\hline 9 & Київська & 24 & 69 & 45 \\
\hline 10 & Кропивницька & 27 & 48 & 21 \\
\hline 11 & Луганська & 18 & 37 & 19 \\
\hline 12 & Львівська & 41 & 73 & 32 \\
\hline 13 & Миколаївська & 42 & 52 & 10 \\
\hline 14 & Одеська & 37 & 91 & 54 \\
\hline 15 & Полтавська & 53 & 61 & 8 \\
\hline 16 & Рівненська & 45 & 64 & 19 \\
\hline 17 & Сумська & 38 & 51 & 13 \\
\hline 18 & Тернопільська & 54 & 55 & 1 \\
\hline 19 & Харківська & 23 & 56 & 33 \\
\hline 20 & Херсонська & 33 & 49 & 16 \\
\hline 21 & Хмельницька & 51 & 60 & 9 \\
\hline 22 & Черкаська & 57 & 67 & 10 \\
\hline 23 & Чернівецька & 37 & 52 & 15 \\
\hline \multirow[t]{2}{*}{24} & Чернігівська & 50 & 57 & 7 \\
\hline & & 983 & 1466 & \\
\hline
\end{tabular}

Джерело: [2]

Таблиця 4

Європейський досвід проєктів сталого розвитку сільських територій

\begin{tabular}{|c|c|c|}
\hline & Основні складові & Характеристика програм \\
\hline $\mathbf{I}$ & Комплексність & $\begin{array}{l}\text { Проєкти розвитку враховують усі можливі види економічної діяльності, заняття якими можуть } \\
\text { збільшити доходи сільського населення. Кожна пропозиція щодо збільшення зайнятості та дохо- } \\
\text { дів повністю виправдана } 3 \text { юридичної, економічної та соціальної точки зору. Вирішення пр-- } \\
\text { блеми зайнятості та зростання доходів узгоджується з вирішенням інших регіональних проблем } \\
\text { та розвитком сільських територій загалом; }\end{array}$ \\
\hline II & Відкритість & $\begin{array}{l}\text { У розвитку проєктної діяльності використовують методи інтерактивного (за участю населення) } \\
\text { планування; досягнуті результати та проблеми всебічно висвітлюються в місцевих засобах масо- } \\
\text { вої інформації, обговорюються на сільських зборах, зустрічах з населенням; за результатами цих } \\
\text { обговорень слід внести відповідні корективи в проєкти; }\end{array}$ \\
\hline III & $\begin{array}{c}\text { Широка участь } \\
\text { населення }\end{array}$ & $\begin{array}{l}\text { У процесі розробки та реалізації проєктів знання, досвід та уявлення населення про найефек- } \\
\text { тивніші способи забезпечення зайнятості та доходу використовуються максимально, врахову- } \\
\text { ються особливості економічної та соціальної поведінки різних соціальних груп, узгоджуються їх } \\
\text { інтереси та наміри, спільними зусиллями консолідується місцеве самоврядування та діяльність } \\
\text { громадських організацій; }\end{array}$ \\
\hline IV & $\begin{array}{c}\text { Опора на місцеві } \\
\text { ресурси }\end{array}$ & $\begin{array}{l}\text { Досягнення цілей сталого розвитку сільських територій забезпечується, перш за все, шляхом } \\
\text { мобілізації місцевих фінансових, матеріально-технічних, соціальних та природних ресурсів, що } \\
\text { має першочергове значення для створення стійких механізмів зайнятості та доходів населення. } \\
\text { Але це не виключає використання зовнішніх джерел ресурсів для розвитку села. }\end{array}$ \\
\hline
\end{tabular}

Джерело: сформовано за результатами дослідження [7]

фінансові ресурси [6]. На рис. 6 наведено інформацію щодо частки доходів ОТГ України у доходах місцевих бюджетів (загальний фонд). На рис. 7 наведено інформацію щодо динаміки частки власних доходів місцевих бюджетів (загальний фонд) у ВВП України. На рис. 8. наведено інформацію щодо власних доходів загального фонду місцевих бюджетів.

В ході децентралізації повноваження щодо надання соціальних послуг населенню переходять 3 центрального рівня на місцевий, тобто до об'єднаних територі- 
Розвиток продуктивних сил і регіональна економіка

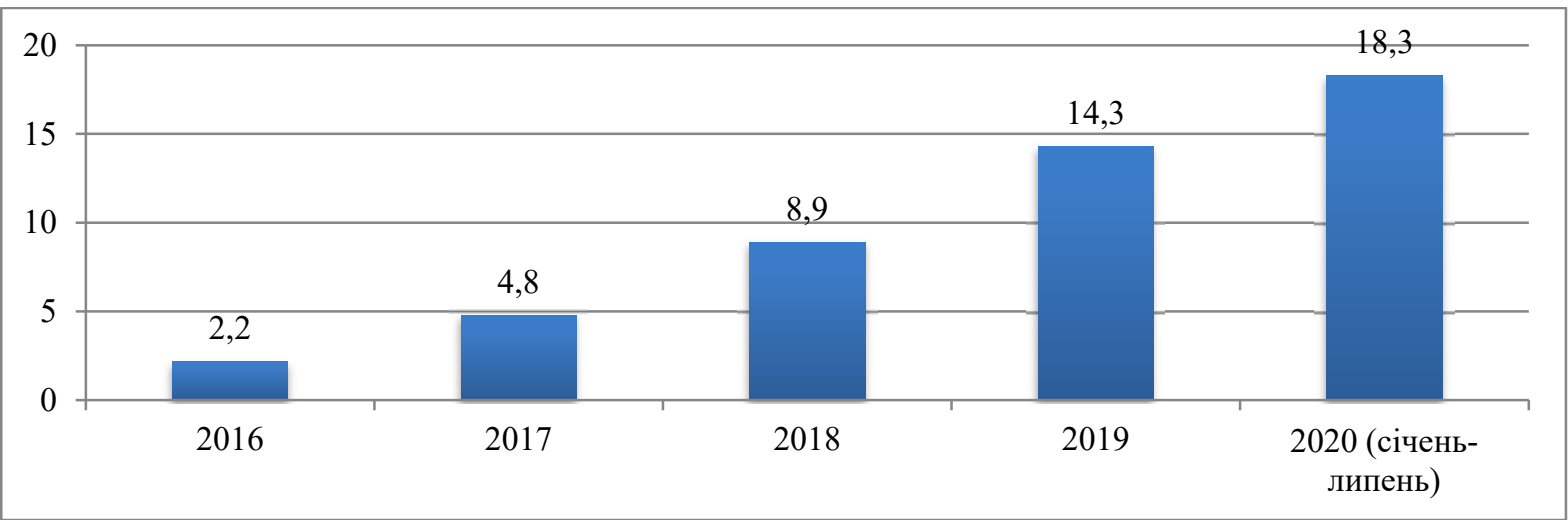

Рис. 6. Частка доходів ОТГ Украӥни у доходах місцевих бюджетів (загальний фонд), \% Джерело: [2]

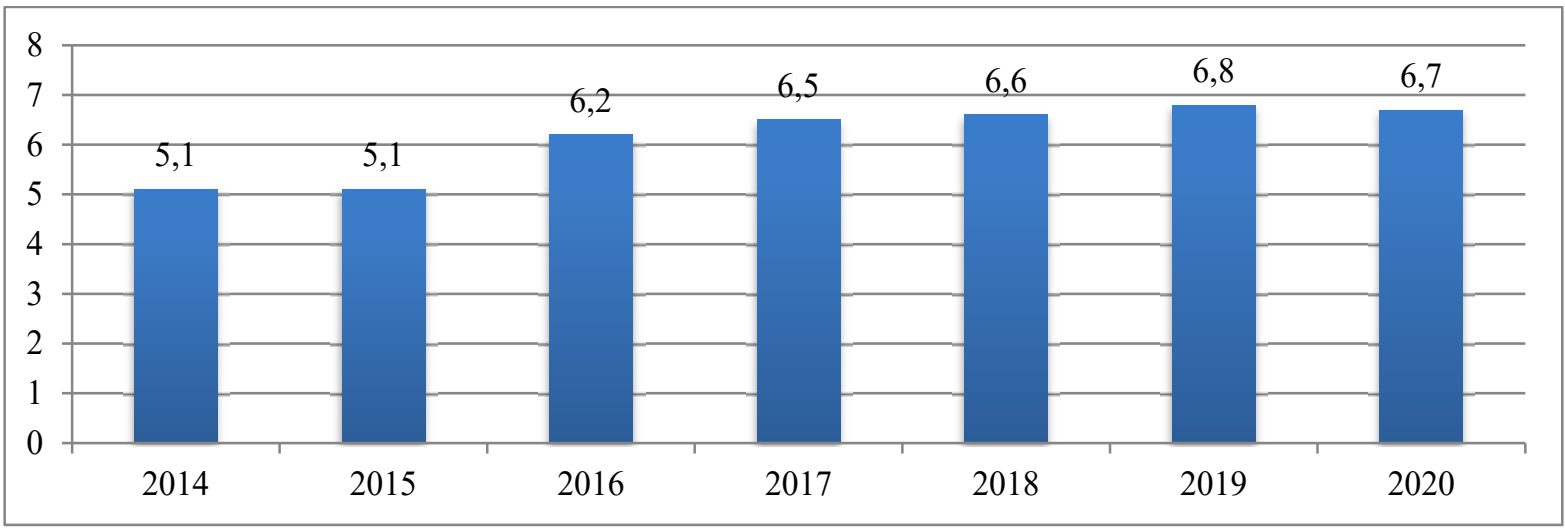

Рис. 7. Динаміка частки власних доходів місцевих бюджетів (загальний фонд) у ВВП, \% Джерело: [2]

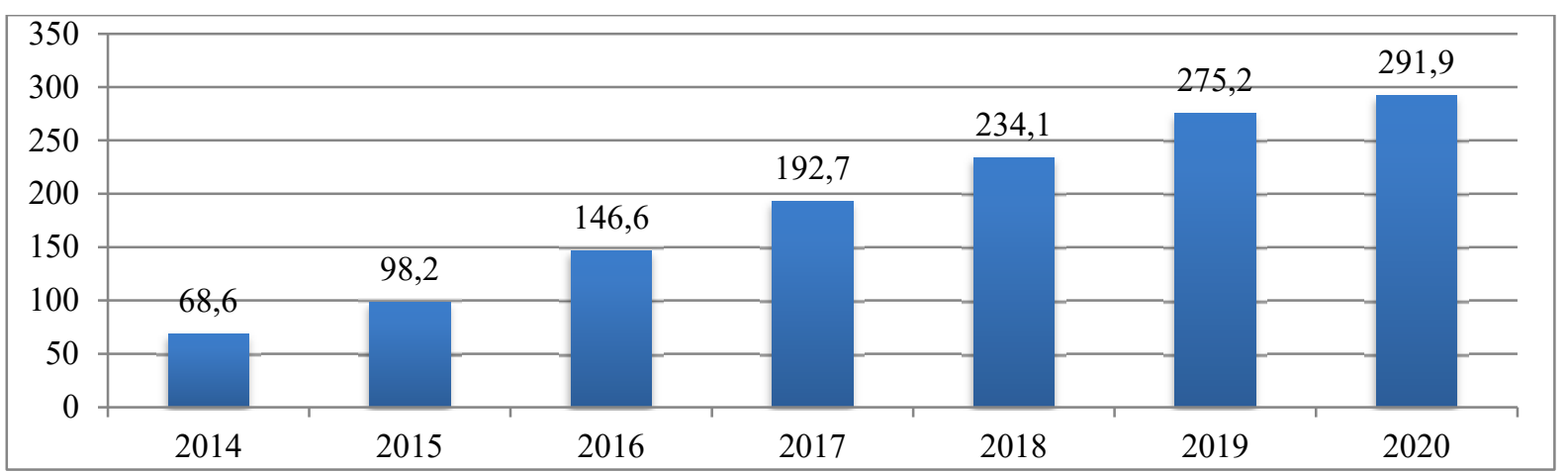

Рис. 8. Власні доходи загального фонду місцевих бюджетів, млрд. грн.

Джерело:[2]

альних громад. 31 січня 2020 року стає чинною нова редакція Закону України «Про соціальні послуги». Таким чином, з початку

2020 року змінився розподіл повноважень центральних та місцевих органів влади, а також встановлена система соціальних послуг та іiі учасників [3], етапи визначення потреб, планування, організація та фінансування соціальних послуг.
Повноваження у сфері соціальних послуг передаються громадам - максимально наближеним до одержувачів цих послуг. Такі повноваження визначені новою редакцією Закону як власні повноваження громад. Для їх реалізації громада повинна створити відповідний структурний підрозділ. Кожна ОТГ буде зобов'язана надавати базові соціальні послуги. Водночас, кожна соціальна послуга надаватиметься за 


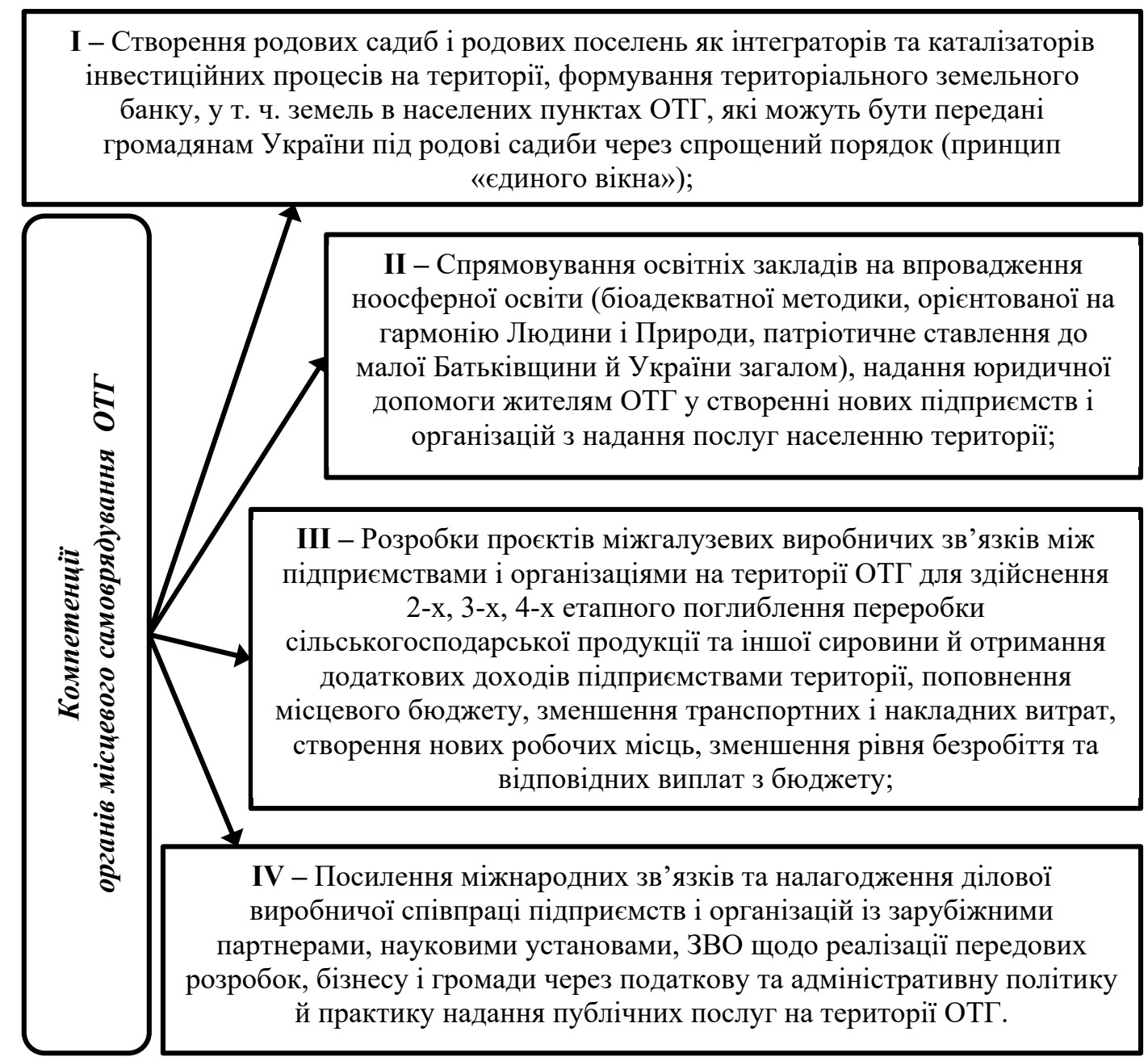

Рис. 9. Основні функції органів місцевого самоврядування ОТГ

Докерело: сформовано за результатами дослідження

відповідним соціальним стандартом, який затверджує Міністерство соціальної політики [14].

Розвиток сільських територій за рахунок функцій, що віднесені до компетенції органів місцевого самоврядування ОТГ, забезпечує сприятливі умови для соціально-економічного розвитку (рис. 9).

Одночасно з диверсифікацією господарської діяльності необхідно особливу увагу приділяти підвищенню ефективності сільського господарства. Як зазначає Лупенко Ю.О., в Україні сформувалося п'ять основних моделей розвитку сільських територій (рис. 10).

У цьому контексті окремої уваги заслуговує територіальна або кластерна модель розвитку сільських територій. Вона найкраще розкриває потенціал реформи децентралізації, спрямованої на збільшення управлінської та економічної незалежності регіонів [11]. Оскільки це дозволяє розглядати два елементи мезоекономіки - території та міжгалузеві комплекси як взаємодоповнюючі чинники формування регіональних соціально-економічних систем.

Однак соціальний добробут, трудова та політична активність сільського населення перебувають на пасивно-очікуваному рівні, що пояснюється низкою причин: значним роз'єднанням у країні соціально-економічних та політичних процесів, цінностей людей та соціальних очікувань; недостатня обізнаність населення про причини кризи, характер ринкових відносин, специфічні способи самоініціативи в цих умовах; низький рівень політичної та моральної довіри до колишніх, а тепер сформованих інститутів влади, партій та рухів; відсутність реального досвіду, переконливих та успішних дій у ринкових умовах; страх безробіття, дефекти соціальної інфраструктури, культури та дозвілля, нормального життя, соціального забезпечення тощо [9; 10].

Проблеми також полягають у кваліфікації управлінського персоналу для розподілу та адміністрування бюджету громади, необгрунтованих надій на залучення грантів, інвестицій та коштів із різних програм без стратегічного бачення перспектив розвитку та механізмів його забезпечення [15]. Основи реорганізації економічного механізму територіального управління, закладені нормативно-правовою базою в контексті територіальної реформи та децентралізації влади, юридично забез- 


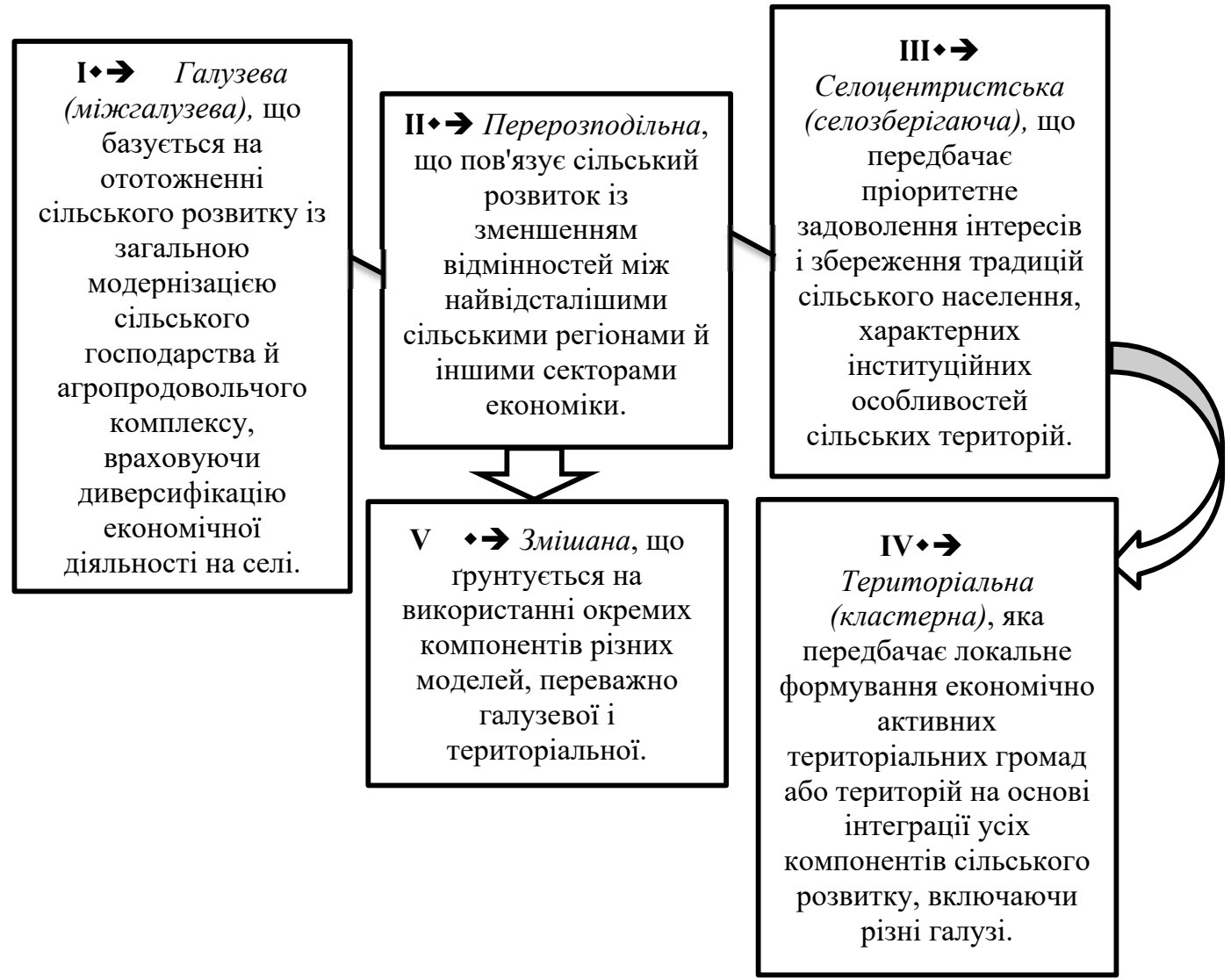

Рис. 10. Основні моделі розвитку сільських територій

Джерело: [8]

печили незалежність регіонів. Водночас розширення повноважень органів місцевого самоврядування передбачає відповідальність за соціально-економічний розвиток сільської місцевості, використання ресурсного потенціалу, активізацію економічної діяльності та державно-приватного партнерства в регіоні $[15 ; 16]$.

Окремої уваги заслуговує питання інклюзивного розвитку сільських територій. В сучасних умовах ідея інклюзивності активно розвивається і просувається на рівні найавторитетніших світових організацій. Інклюзивне зростання визначається як «зростання, яке не тільки створює нові економічні можливості, але й забезпечує рівний доступ до них для всіх верств населення, особливо для його вразливих представників». Необхідним компонентом ефективної реалізації концепції інклюзивного розвитку регіону є забезпечення належного рівня фінансової децентралізації, імперативами якої є достатнє фінансування місцевих бюджетів, розширення повноважень органів місцевого самоврядування щодо отримання доходів та ефективна система контролю [17], налагодженої з метою уникнення системного зловживання владою посадових осіб на найбільш відповідальних посадах.

Однією $з$ форм інклюзивних економічних інститутів є бюджет участі - демократичний процес, який надає можливість кожному жителю брати участь в роз- поділі коштів місцевого бюджету через створення проєктів для покращення міста/ОТГ та/або голосування за них. Будь-який житель міста/ОТГ може подати проєкт, пов'язаний з покращенням життя в місті/ОТГ, взяти участь у конкурсі, перемогти в голосуванні і спостерігати за тим, як його проєкт реалізують в рамках бюджету року [17]. Тому провідною рисою розвитку сільських поселень на сучасному етапі має стати інклюзивність, тобто активне залучення до процесу поточних реформ усіх суб'єктів, кожен з яких є важливим і цінним, незалежно від рівня їх соціально-економічного розвитку та наявного потенціалу.

За сучасних умов уряди багатьох країн, як економічно розвинених, так і бідних, намагаються реалізувати концепцію інклюзивного розвитку, розглядаючи іiі як ефективний засіб наслідків ускладнення суспільнополітичної та соціально-економічної ситуації в країні та світі [5; 12]. Безсумнівно, що будь-які соціальні програми та проєкти, включаючи ті, що реалізуються у сільській місцевості, повинні грунтуватися на ідеї соціальної інклюзії.

У контексті питань врегулювання інклюзивність набуває більш широкого тлумачення, оскільки передбачає залучення для потреб сільського розвитку незалучених місцевих ресурсів та можливостей - матеріальних, людських, фінансових. 
Засади державної регіональної політики

\begin{tabular}{|c|c|c|c|c|}
\hline \multicolumn{5}{|c|}{ Основні характеристики } \\
\hline I & II & III & IV & $\mathbf{V}$ \\
\hline $\begin{array}{c}\text { Стимулювання й під- } \\
\text { тримку місцевих ініціа- } \\
\text { тив щодо ефективного } \\
\text { використання вну- } \\
\text { трішнього потенціалу } \\
\text { регіонів для створення } \\
\text { повноцінного життє- } \\
\text { вого середовища, під- } \\
\text { вищення якості життя } \\
\text { людей; }\end{array}$ & $\begin{array}{c}\text { Зменшення } \\
\text { територіальної } \\
\text { диференціації за } \\
\text { індексом регіонального } \\
\text { людського розвитку; }\end{array}$ & $\begin{array}{l}\text { Розроблення й реаліза- } \\
\text { цію програм і проєктів } \\
\text { підвищення конку- } \\
\text { рентоспроможності } \\
\text { територій; }\end{array}$ & $\begin{array}{c}\text { Поліпшення матері- } \\
\text { ального, фінансового, } \\
\text { інформаційного, кадро- } \\
\text { вого та іншого ресурс- } \\
\text { ного забезпечення } \\
\text { розвитку регіонів; }\end{array}$ & $\begin{array}{c}\text { Сприяння здійсненню } \\
\text { повноважень органами } \\
\text { місцевого самовряду- } \\
\text { вання. }\end{array}$ \\
\hline
\end{tabular}

Джерело: [15]

В українських реаліях існує значний невикористаний потенціал інклюзивності у формі самоорганізації сільських територіальних громад та продуктивної діяльності сільського бізнесу у вирішенні місцевих соціально-економічних проблем, реалізація яких сприятиме інтеграційним процесам у поселенській мережі на основі розгалуження міжпоселенських взаємозв'язків шляхом модернізації дорожньотранспортної інфраструктури, логістичних систем та інших засобів комунікаційного зв'язку [5; 8].

Безпека сільських поселень досягається шляхом раціонального планування їх території та оптимального розташування виробничих та невиробничих приміщень з урахуванням вимог техногенної та природної безпеки, санітарно-гігієнічних норм і стандартів, правил запобігання надзвичайним ситуаціям. Для реалізації державної регіональної політики, яка визначає правові, економічні, соціальні, екологічні, гуманітарні й організаційні основи регіонального розвитку, було прийнято Закон України «Про засади державної регіональної політики» [17] (табл. 5).

Повноваження та ресурси, отримані в результаті децентралізації, надали органам місцевого самоврядування більше можливостей для розвитку територій, створення сучасної освітньої, медичної, транспортної, житлово-комунальної інфраструктури. Нині місцева влада зацікавлена у розвитку інвестиційної привабливості своїх територій на благо громади, оскільки податки, що сплачуються тут, покращать якість життя мешканців цієї території. На місцях будуть доступні різні дозволи та реєстраційні документи для ведення бізнесу, громади зможуть залучати інвестиції [4], сприяючи соціально-економічному розвитку.

Місцеве самоврядування, насамперед, має спрямовувати діяльність ОТГ на організацію стратегічних соціально-економічних завдань, науково-технічних проєктів підприємств та організацій, що знаходяться на іiі території. Важливо сприяти пошуку та впровадженню найбільш ефективних форм співпраці всіх учасників суспільних процесів, включаючи науково-дослідні установи, заклади вищої освіти (ЗВО), виробників, активізацію формування регіонального кластеру. Стратегічні цілі управління ОТГ мають грунтуватися на досягненні саморозвитку, самодостатності та самозайнятості шляхом використання внутрішнього потенціалу громади [15; 18], що призведе до самодостатності у всіх сферах іiі життя.

В умовах процесу децентралізації влади в Україні виникають нові можливості розвитку сільських територій. Перспективи місцевого розвитку, відтворення соціальної сфери, боротьба з бідністю, підвищення рівня життя сільського населення, відновлення закладів культури, охорони здоров'я тощо виступають основним мотиваційним чинником децентралізації для територіальних громад [11]. В умовах децентралізації влади органи місцевого самоврядування мають потенціал функціонувати ефективніше, ніж центральні органи. Територіальні громади можуть регулювати процес накопичення коштів, надання відповідних послуг на основі коротко- та довгострокового планування. Розширення прав та можливостей органів місцевого самоврядування на різних рівнях має здійснюватися таким чином, щоб, з одного боку, максимально наблизити процес прийняття рішень до громадян, а з іншого боку, забезпечити, щоб органи влади володіли організаційними, матеріальними та фінансовими ресурсами для забезпечення належного рівня життя та якості послуг, що надаються населенню відповідно до національних соціальних стандартів [16; 18].

Можна також стверджувати, що децентралізацію слід розглядати як фактор, який безпосередньо впливає на диверсифікацію розвитку сільських територій. Адже ми розглядаємо диверсифікацію розвитку села як комплекс заходів, спрямованих на урізноманітнення сільськогосподарської та несільськогосподарської діяльності у сільській місцевості, розширення джерел фінансування заходів, організованих ОТГ, у межах стратегій $[12 ; 14]$, програм та проєктів розвитку села 3 метою розширення сфер зайнятості та доходів сільського населення на основі комплексного підходу.

Висновки. Завдання уряду сприяти розвитку місцевого самоврядування в умовах переходу до децентралізації державного управління - забезпечити включення мотиваційного чинника реформування місцевого самоврядування. 
Лише інтерес до результатів сприятиме активізації роботи органів місцевого самоврядування у напрямку пошуку шляхів розширення власної фінансової бази. Децентралізація державного управління в цьому аспекті проявляється, зокрема, у наданні місцевим органам влади можливості виходу на фінансовий ринок
3 метою накопичення додаткових фінансових ресурсів для бюджетів розвитку. Такий підхід дозволить органам місцевого самоврядування отримати доступ до фінансових ресурсів, що циркулюють на регіональних ринках, і перетворити їх на інвестиції в місцевий розвиток.

\section{Список літератури:}

1. Гончарук I.В., Томашук І.В. Державне регулювання розвитку ресурсного потенціалу сільських територій: загальні аспекти. Економіка, фінанси, менеджмент: актуальні питання науки і практики. 2018. № 4 (32). С. 19-30.

2. Децентралізація дає можливості. URL: https://decentralization.gov.ua/news/12055 (дата звернення: 29.07.2021).

3. Довгаль О.В. Розвиток сільських територій в умовах децентралізації. Украйнський журнал прикладної економіки. 2018. Том 3. № 4. С. 268-279.

4. Сгорова В.С. Процес децентралізації влади в Україні. Часопис Київського університету права. 2017. № 4. С. 66-69.

5. Заяць Т.А. Розвиток сільських поселень України в умовах децентралізації: можливості та ризики. Демографія та соиіальна економіка. 2017. № 3 (31). С. 48-60.

6. Зміни до Конституції України: що ще треба зробити для децентралізації влади. URL: http://www.nbuviap.gov.ua/ index.php?option=com_content\&view=article \&id=4303:perspektivi-prosuvannya-detsentralizatsiji-v-ukrajini\&catid=8\&Ite mid=350 (дата звернення: 06.08.2021).

7. Калетнік Г.М., Смчик Т.В. Державне регулювання соціально-економічного розвитку сільських територій в Україні. Економіка, фінанси, менеджмент: актуальні питання науки і практики. 2020. № 2. С. 7-22.

8. Лупенко Ю.О. Стан та перспективи сталого розвитку сільських територій. Економіка АПК. 2017. № 6. С. 7-10.

9. Луцяк В.В., Томашук І.В. Екологічний менеджмент потенціалу Вінницької області. Економіка, фінанси, менеджмент: актуальні питання науки і практики. 2019. № 1. С. 33-47.

10. Mazur K.V., Tomashuk I.V. Governance and regulation as an indispensable condition for developing the potential of rural areas. Baltic Journal of Economic Studies. 2019. Vol. 5. № 5. P. 67-78.

11. Мудрак Р.П., Лагодієнко В.В., Лагодієнко Н.В. Вплив сукупних витрат на обсяги національного виробництва. Економічний часопис - XXI. 2018. № 172 (7-8). С. 44-50.

12. Мовчанюк А.В. Соціально-економічні аспекти розвитку сільських територій в умовах децентралізації влади. Східна Свропа: економіка, бізнес та управління. 2017. Вип. 2 (07). С. 193-196.

13. Реформа місцевого самоврядування та децентралізація влади. URL: https://rpr.org.ua/groups-rpr/ 04detsentralizatsiya/ (дата звернення: 11.08.2021).

14. Реформа сфери соціальних послуг в умовах децентралізації. URL: https://decentralization.gov.ua/social (дата звернення: 21.07.2021).

15. Россоха В., Плотнікова М. Розвиток сільських територій України в умовах децентралізації управління: стан, проблеми, перспективи. Економічний дискурс. 2018. Вип. 4. С. 41-53.

16. Талавиря М.П., Горай А.О. Розвиток сільських територій в умовах децентралізації. Економіка АПК. 2018. № 11. C. 75-79.

17. Цимбалюк І.О. Концептуальні засади інклюзивного розвитку регіону в умовах фінансової децентралізації. Інновачійна економіка. 2019. № 5-6 (80). С. 125-132.

18. Шпикуляк О.Г., Мазур Г.Ф. Інституційні засади формування соціального капіталу в механізмі розвитку сільських територій. Економіка АПК. 2014. № 8. С. 63.

\section{References:}

1. Honcharuk I.V., Tomashuk I.V. (2018) Derzhavne rehuliuvannia rozvytku resursnoho potentsialu silskykh terytorii: zahalni aspekty [State regulation of resource potential development in rural areas: general aspects]. Economics, finance, management: current issues of science and practice, no. 4(32), pp. 19-30. (in Ukrainian)

2. Detsentralizatsiia daie mozhlyvosti [Decentralization provides opportunities]. Available at: https://decentralization.gov.ua/ news/12055 (accessed 29 July 2021).

3. Dovhal O.V. (2018) Rozvytok silskykh terytorii v umovakh detsentralizatsii [Development of rural areas in the conditions of decentralization]. Ukrainian Journal of Applied Economics, t. 3, no. 4, pp. 268-279. (in Ukrainian)

4. Yehorova V.S. (2017) Protses detsentralizatsii vlady v Ukraini [The process of decentralization of power in Ukraine]. Journal of Kyiv University of Law, no. 4, pp. 66-69. (in Ukrainian)

5. Zaiats T.A. (2017) Rozvytok silskykh poselen Ukrainy v umovakh detsentralizatsii: mozhlyvosti ta ryzyky [Development of rural settlements of Ukraine in the conditions of decentralization: opportunities and risks]. Demography and social economy, no. 3 (31), pp. 48-60. (in Ukrainian)

6. Zminy do Konstytutsii Ukrainy: shcho shche treba zrobyty dlia detsentralizatsii vlady [Amendments to the Constitution of Ukraine: what else needs to be done to decentralize power]. Available at: http://www.nbuviap.gov.ua/index.php?option=com content\&view=article \&id=4303:perspektivi-prosuvannya-detsentralizatsiji-v-ukrajini\&catid=8\&Itemid=350 (accessed 06 August 2021). 
7. Kaletnik H.M., Yemchyk T.V. (2020) Derzhavne rehuliuvannia sotsialno-ekonomichnoho rozvytku silskykh terytorii $\mathrm{v}$ Ukraini [State regulation of socio-economic development of rural areas in Ukraine]. Economics, finance, management: current issues of science and practice, no. 2, pp. 7-22. (in Ukrainian)

8. Lupenko Yu.O. (2017) Stan ta perspektyvy staloho rozvytku silskykh terytorii [Status and prospects of sustainable development of rural areas]. Economics of agro-industrial complex, no. 6, pp. 7-10. (in Ukrainian)

9. Lutsiak V.V., Tomashuk I.V. (2019) Ekolohichnyi menedzhment potentsialu Vinnytskoi oblasti [Екологічний менеджмент потенціалу Вінницької області]. Economics, finance, management: current issues of science and practice, no. 1, pp. 33-47. (in Ukrainian)

10. Mazur K.V., Tomashuk I.V. (2019) Governance and regulation as an indispensable condition for developing the potential of rural areas. Baltic Journal of Economic Studies, vol. 5, no. 5, pp. 67-78. (in Latvia)

11. Mudrak R.P., Lahodiienko V.V., Lahodiienko N.V. (2018) Vplyv sukupnykh vytrat na obsiahy natsionalnoho vyrobnytstva [The impact of total costs on national production]. Economic Journal - XXI, no. 172(7-8), pp. 44-50. (in Ukrainian)

12. Movchaniuk A.V. (2017) Sotsialno-ekonomichni aspekty rozvytku silskykh terytorii v umovakh detsentralizatsii vlady [Socio-economic aspects of rural development in the context of decentralization of power]. Eastern Europe: Economy, Business and Management, vol. 2 (07), pp. 193-196. (in Ukrainian)

13. Reforma mistsevoho samovriaduvannia ta detsentralizatsiia vlady [Local government reform and decentralization of power]. Available at: https://rpr.org.ua/groups-rpr/04detsentralizatsiya/ (accessed 11 August 2021).

14. Reforma sfery sotsialnykh posluh $\mathrm{v}$ umovakh detsentralizatsii [Reform of social services in the context of decentralization]. Available at: https://decentralization.gov.ua/social (accessed 21 August 2021).

15. Rossokha V., Plotnikova M. (2018) Rozvytok silskykh terytorii Ukrainy v umovakh detsentralizatsii upravlinnia: stan, problemy, perspektyvy [Development of rural areas of Ukraine in the conditions of decentralization of management: state, problems, prospects]. Economic discourse, vol. 4, pp. 41-53. (in Ukrainian)

16. Talavyria M.P., Horai A.O. (2018) Rozvytok silskykh terytorii v umovakh detsentralizatsii [Development of rural areas in the conditions of decentralization]. Economics of agro-industrial complex, no. 11, pp. 75-79. (in Ukrainian)

17. Tsymbaliuk I.O. (2019) Kontseptualni zasady inkliuzyvnoho rozvytku rehionu v umovakh finansovoi detsentralizatsii [Conceptual principles of inclusive development of the region in the conditions of financial decentralization]. Innovative economy, no. 5-6 (80), pp. 125-132. (in Ukrainian)

18. Shpykuliak O.H., Mazur H.F. (2014) Instytutsiini zasady formuvannia sotsialnoho kapitalu v mekhanizmi rozvytku silskykh terytorii [Institutional principles of social capital formation in the mechanism of rural development]. Economics of agro-industrial complex, no. 8, pp. 63. (in Ukrainian)

\section{РАЗВИТИЕ СЕЛЬСКИХ ТЕРРИТОРИЙ В УСЛОВИЯХ ДЕЦЕНТРАЛИЗАЦИИ ВЛАСТИ В УКРАИНЕ}

В статье рассмотрены меры реорганизации экономического механизма территориального управления в контексте децентрализации власти. Указывается, что реформа децентрализации непосредственно связана с развитием и оптимальным использованием ресурсного потенциила сельских территорий. Отмечается, что одной из фундаментальных условий независимости органов местного самоуправления является финансовая децентрализация, которая отражает финансовые полномочия региональных органов власти. Отмечается, что процесс добровольного объединения территориальных общин создал предпосылки для трансформации территориальной структуры и субрегионального уровня. Подчеркивается, что в украинских реалиях существует значительный неиспользованный потенциил инклюзивности в форме самоорганизации деятельности сельских территориальньхх общин и продуктивной деятельности сельского бизнеса в решении местньх сочиально-экономических проблем. Сделаны выводы, что территориальные общины могут регулировать процесс накопления средств, предоставления соответствуюших услуг, основываясь на кратко- и долгосрочном планировании. Также можно утверждать, что децееттрализацию следует рассматривать как фактор, который напрямую влияет на диверсификаиию развития сельских территорий.

Ключевые слова: децентрализация, сельские территории, объединенные территориальные общины, инклюзивный развитие, потенциил, Государственный фонд регионального развития.

\section{DEVELOPMENT OF RURAL AREAS IN CONDITIONS OF DECENTRALIZATION OF POWER IN UKRAINE}

The article considers measures of reorganization of the economic mechanism of territorial administration in the context of decentralization of power. It is indicated that the decentralization reform is directly related to the development and optimal use of the resource potential of rural areas. It is emphasized that one of the fundamental conditions for the independence of local governments is financial decentralization, which reflects the financial powers of regional authorities. It is stated that the process of voluntary unification of territorial communities has created the preconditions for the transformation of the territorial structure and subregional level. It is emphasized that the main alternatives to agriculture 
today are the spheres of construction, trade, social services, etc. It is highlighted that in the Ukrainian realities there is a significant untapped potential of inclusiveness in the form of self-organizational activity of rural territorial communities and productive activity of rural business in solving local socio-economic problems. Modern decentralization changes in the country and its regions are carried out by intensifying the self-government of territorial communities, which must clearly understand their own needs and the need to achieve balanced development of settlements, be sufficiently motivated as permanent residents and interested in economic growth and social prosperity. The leading feature of the development of rural settlements at the present stage should be inclusiveness, ie active involvement in the process of ongoing reforms of all actors, each of which is important and valuable, regardless of their level of socio-economic development and available potential. It is concluded that local communities can regulate the process of accumulation of funds, provision of appropriate services, based on short-and long-term planning. It can also be argued that decentralization should be seen as a factor that directly affects the diversification of rural development.

Key words: decentralization, rural areas, united territorial communities, inclusive development, potential, State Fund for Regional Development. 